\title{
Comparative growth and physiological responses of tetraploid and hexaploid species of wheat to flooding stress
}

\author{
Mohammad Sadegh KHOSRAVI ${ }^{1,2}$, Reza HEIDARI ${ }^{2}$, Rashid JAMEI ${ }^{2}$, Seyed Mousa MOUSAVI KOUHI ${ }^{*}$, \\ Maryam MOUDI $^{1}$
}

Received July 27, 2017; accepted July 29, 2018.

Delo je prispelo 27. julija 2017, sprejeto 29. julija 2018.

\begin{abstract}
Present study is aimed to comparatively investigate the response of two ploidy levels of wheat including a tetraploid (Triticum turgidum L.) and a hexaploid (Triticum aestivum L.) wheat to different durations of flooding stress. Wheat seedlings were exposed to flooding stress for $0,3,6$ and 9 days. Results showed that all flooding treatments significantly decreased the shoot and root length, and chlorophyll content of both species of wheat. The decrease in chlorophyll content of tetraploid wheat was more than that of hexaploid one. In both species, $\mathrm{ADH}$ activity of root was significantly increased under flooding stress, where the increase was more in hexaploid wheat. Flooding stress did not significantly affect root and shoot water content, root porosity, and shoot protein content of any wheat species. Tetraploid and hexaploid wheat used different mechanisms for better tolerance of flooding condition, where tetraploid wheat increased the proline content but in hexaploid wheat, an increase in soluble sugar content was observed.
\end{abstract}

Key words: flooding stress; polyploidy; soil water; waterlogging

\section{IZVLEČEK}

\section{PRIMERJALNI RASTNI IN FIZIOLOŠKI ODZIVI TETRAPLOIDNE IN HEKSAPLOIDNE PŠENICE NA POPLAVNI STRES}

$\mathrm{V}$ raziskavi je bil primerjalno preučevan odziv tetraploidne (Triticum turgidum L.) in heksaploidne pšenice (Triticum aestivum L.) na različno trajanje poplavnega stresa. Sejanke pšenice so bile izpostavljene poplavnemu stresu za $0,3,6$ in 9 dni. Rezultati kažejo, da so vsa obravnavanja s poplavitvami značilno zmanjšala dolžino poganjkov in korenin ter vsebnost klorofila pri obeh vrstah pšenice. Zmanjšanje klorofila je bilo večje pri tetraploidni kot pri heksaploidni pšenici. Pri obeh vrstah se je v razmerah poplavnega stresa aktivnost alkohol dehidrogenaze $(\mathrm{ADH}) \mathrm{v}$ koreninah značilno povečala, a bolj pri heksaploidni vrsti. Poplavni stres ni značilno vplival na vsebnost vode $\mathrm{v}$ koreninah in poganjkih, niti na poroznost korenin in vsebnost beljakovin pri obeh vrstah. Tetraploidna in heksaploidna pšenica sta uporabili različne mehanizme tolerance na poplavne razmere, tetraploidna s povečanjem vsebnosti prolina, heksaploidna s povečanjem vsebnosti topnih sladkorjev.

Ključne besede: poplavni stres; poliploidija; talna voda; zalitje $\mathrm{z}$ vodo

\section{INTRODUCTION}

Waterlogging is defined as prolonged soil saturation with water, at least $20 \%$ higher than the field capacity (Aggarwal et al., 2006). Anaerobic root respiration can induce an accumulation of potentially toxic metabolites such as ethanol, lactic acid, acetaldehyde and cyanogenic compounds. For instance, the accumulation of lactic acid can induce cytosolic acidosis, resulting in the cell death (Kozlowski, 1997; Liao and Lin, 2001; Jackson, 2002; Ashraf, 2012). Since gas diffuses about 4 times more slowly through water than through air, a reduced supply of oxygen during waterlogging may result in halting of growth and survival of many species (Drew, 1997). This is because most tissues of higher plants could not survive under anaerobic condition (Taiz and Zeiger, 2010).

Plants respond to flooding stress by different mechanisms. They have genetic differences in term of the tolerance to waterlogging (Fausey et al., 1985; Vantoai et al., 1988; Davies and Hillman, 1988). Short-

\footnotetext{
1 Department of Biology, Faculty of Science, University of Birjand, Birjand, Iran, *corresponding author: Smmousavi@birjand.ac.ir

2 Department of Biology, Faculty of Science, Urmia University, Urmia, Iran
} 
term acclimation including biochemical mechanisms may decrease the negative impacts of flooding (Vartapetian and Jackson, 1997). However, some plants such as wetland species are adapted to flooding due to the specialized structures such as aerenchyma and structural barriers to prevent $\mathrm{O}_{2}$ diffusion outward to the soil (Vartapetian and Jackson, 1997; Bacanamwo and Purcell, 1999; Taiz and Zeiger, 2010). Acclimation to the anaerobic conditions may involve the expression of anaerobic stress genes, mainly the enzymes of the glycolytic and fermentation pathways such as alcohol dehydrogenase (Taiz and Zeiger, 2010).

Wheat is one the most important crops that was domesticated approximately 10,000 years ago. Wheat is a polyploid plant, originated by hybridization between different species (allopolyploidy) (Dubcovsky and Dvorak, 2007). Hexaploid wheat was formed by hybridization of a domesticated form of allotetraploid wheat (Triticum turgidum L.) and a diploid goat grass Aegilops tauschii Coss. With an increase in ploidy level of plants, their physiological performance and their tolerance to biotic and abiotic stresses may be improved (Yang et al., 2014). For instance, it has been reported that hexaploid wheat has greater physiological and ecological plasticity than its tetraploid and diploid progenitors (Dubcovsky and Dvorak, 2007).

The results of present study may have great significance for wheat farming in frequently waterlogged areas. Beside, these results could be used in further agricultural studies on the response of plants to anaerobic condition. Present study aimed to comparatively investigate the response of two ploidy levels of wheat including a tetraploid and a hexaploid wheat to different durations of flooding stress.

\section{MATERIALS AND METHODS}

\subsection{Plant material and treatment conditions}

Seeds of a tetraploid (Triticum turgidum 'Oshnavie') and a hexaploid (Triticum aestivum 'Sardari') wheat were obtained from the Agricultural Research Center of Urmia, West Azarbayjan, Iran. Seeds were surface sterilized with $5 \%$ (v/v) sodium hypochlorite solution for $10 \mathrm{~min}$ (Mousavi Kouhi et al., 2014), rinsed with tape water, and imbedded for $12 \mathrm{~h}$. The seeds were placed in Petri dishes containing moist filter paper and were kept in a dark incubator for $72 \mathrm{~h}$ at $27{ }^{\circ} \mathrm{C}$. Then, 8 seedlings were sown in each plastic pot $(13 \times 16 \mathrm{~cm})$ containing vermiculite. The seedlings were grown in a growth chamber under controlled condition $(26 \pm 2$ and $24 \pm 2 \mathrm{C}^{\circ}$ in condition of $16 \mathrm{~h}$ of light and $8 \mathrm{~h}$ of dark, respectively). Seedlings were independently flooded for 0, 3, 6 and 9 days. For this purpose, plastic pots were water-filled up to $18 \mathrm{~mm}$ above the bed. Control plants were normally irrigated with tap water according to the field capacity (Jamei et al., 2008). At the end of each treatment the roots and shoots of seedlings were harvested separately and then the growth criteria and biochemical and physiological changes of the roots and shoots tissues were investigated.

\subsection{Determination of root porosity and water content of root and shoot}

Root air space was measured by a pycnometer method (Jensen et al., 1969). Water content of root and shoot was determined as WC $=\mathrm{FM}-\mathrm{DM} / \mathrm{FM}$ in which WC, FM, and DM indicate water content, fresh mass, and dry mass, respectively.

\subsection{Determination of chlorophyll}

Chlorophyll $\mathrm{a}$ and $\mathrm{b}$ content were measured in the fresh shoots after extraction with $80 \%$ acetone, according to the spectrophotometric method (Lichtenthaler and Wellbum, 1983). Chlorophyll content was calculated as mg chlorophyll per $\mathrm{g}$ fresh leaf.

\subsection{Determination of proline and protein content of shoot}

Proline content was determined according to the Bates et al. (1973). Protein content was measured as recorded by Lowery et al. (1951). Two separate curves were prepared by different concentrations of proline and egg albumin for determination of proline and protein content, respectively.

\subsection{Determination of soluble sugar}

Phenol-sulfuric method was used to determine soluble sugars. After homogenizing $0.5 \mathrm{~g}$ of roots or shoots, 2 $\mathrm{ml}$ from each sample was taken, and then $1 \mathrm{ml} 5 \%$ phenol and $5 \mathrm{ml} 98 \%$ sulfuric acid was added. After coolness and complete color emergence of the solutions, sugar contents were maintained spectrophotometrically at $485 \mathrm{~nm}$ (Hsu et al., 2000).

\subsection{Assay of alcohol dehydrogenase (ADH) activity of root}

After preparing enzyme extract using $0.1 \mathrm{M}$ Tris- $\mathrm{HCl}$ ( $\mathrm{pH}=8), 0.1 \mathrm{M}$ NADH, $1 \mathrm{mM}$ EDTA, $5 \mathrm{mM}$ sodium borate, $5 \mathrm{mM}$ dithiothreitol, and $10 \%$ glycerol (Hoffman et al., 1986) ADH activity were determined in a $3 \mathrm{ml}$ reaction mixture including $1 \mathrm{ml}$ of $0.5 \mathrm{M}$ Tris- 
$\mathrm{HCl}(\mathrm{pH}=8), 0.5 \mathrm{mM} \mathrm{NAD}, 40 \mathrm{mM}$ ethanol, and $15 \mu \mathrm{l}$ enzyme extract (Donaldson et al., 1985).

\subsection{Statistical Analysis}

A factorial experiment was conducted as completely randomized design with three replicates. Significant differences (at $\mathrm{p} \leq 0.05$ ) and means comparison by Duncan's multiple range test was determined using Mstat-C software.

\section{RESULTS}

\subsection{Growth traits and water content of root and shoot}

Results showed that all flooding treatments significantly decreased the shoot and root length of both tetraploid and hexaploid wheat (Figure 1a \& b). In both species, root growth was more affected by flooding than shoot growth. For instance, while under 9 days flooding the root length of $T$. turgidum and $T$. aestivum was decreased by 55 and $51 \%$, respectively, their shoot length was decreased by 17 and $23 \%$, respectively, compared to their controls. However, shoot and root length of both wheat showed a similar response to flooding stress. Results showed that root and shoot water content of both ploidy levels of wheat was not significantly affected by any level of flooding, compared to their controls (Figure 1c \& d).

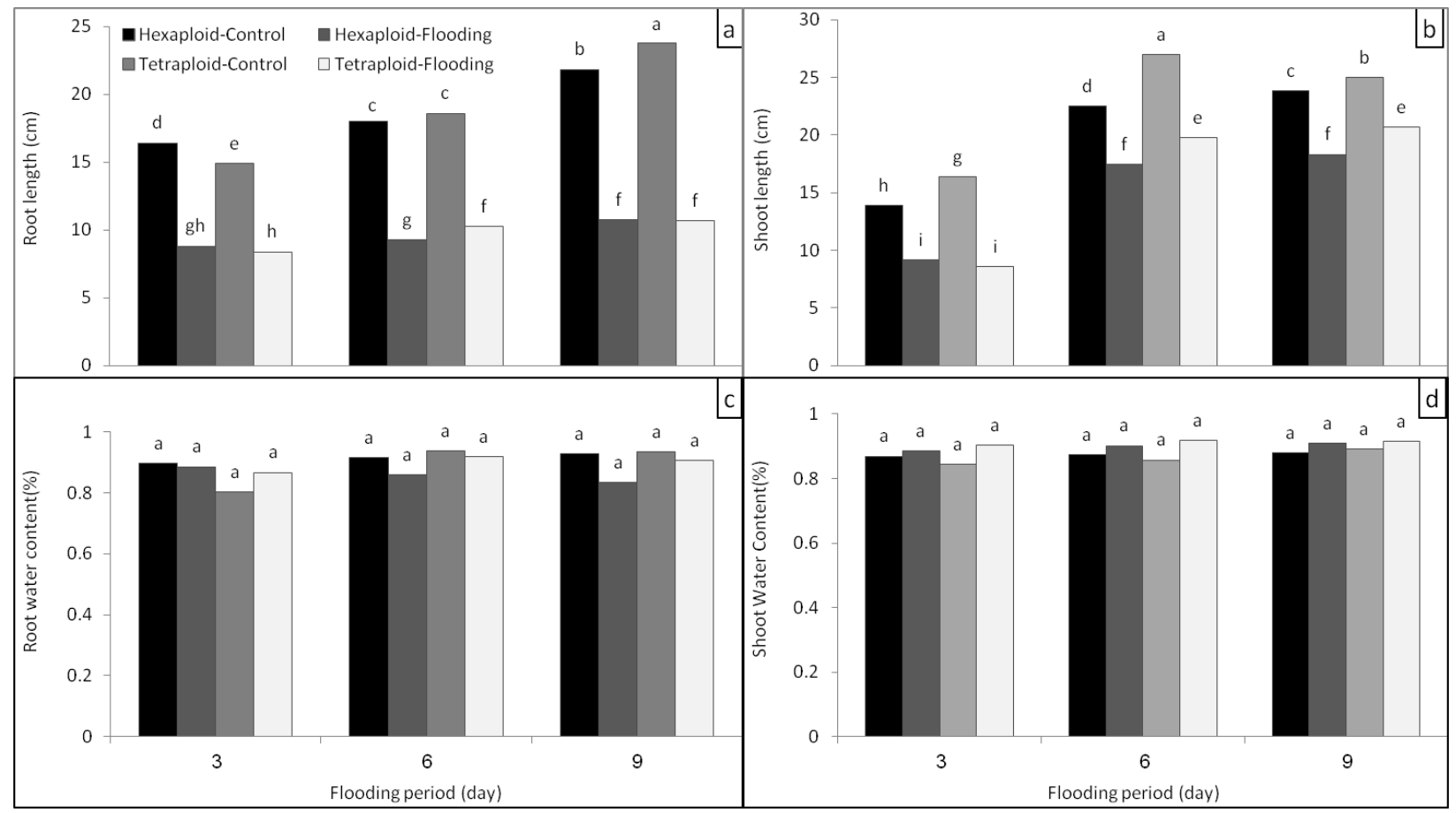

Figure 1: The effect of flooding stress on root (a) and shoot (b) length, and water content of root (c) and shoot (d) of the seedlings of tetraploid and hexaploid wheat. Different letters indicate significant differences $(\mathrm{P}<0.05)$.

\subsection{Chlorophyll a and b content}

The pattern of changes in chlorophyll a and $\mathrm{b}(\mathrm{mg}$ per $\mathrm{g}$ fresh mass) in response to different periods of flooding stress was similar. The flooding stress significantly reduced chlorophyll $\mathrm{a}$ and $\mathrm{b}$ content of both species during all flooding periods (Figure $2 \mathrm{a} \& \mathrm{~b}$ ). However, the decrease in chlorophyll a and b content of tetraploid wheat was more than that of hexaploid one. For instance, while chlorophyll a content of tetraploid wheat under 3,6 , and 9 days flooding was decreased by 61.50 , 46.53 , and $55.28 \%$, respectively, that of hexaploid wheat was decreased by $34.42,22.40$, and $23.87 \%$, respectively. 


\subsection{ADH activity and root porosity}

In root of both ploidy levels of wheat, ADH activity was significantly increased under all periods of flooding, compared to the control (Figure 2c). The increase in $\mathrm{ADH}$ activity in root of hexaploid wheat was more intensive than that of tetraploid one. For instance, while under 3, 6, and 9 days flooding the root ADH activity of hexaploid wheat showed a 38-, 37-, and 62-fold increase over control, respectively, that of tetraploid was increased 33-, 51-, and 57-fold relative to control, respectively. Flooding stress did not also significantly affect root porosity of any species of wheat, when each treatment compared with its control (Figure 2d).

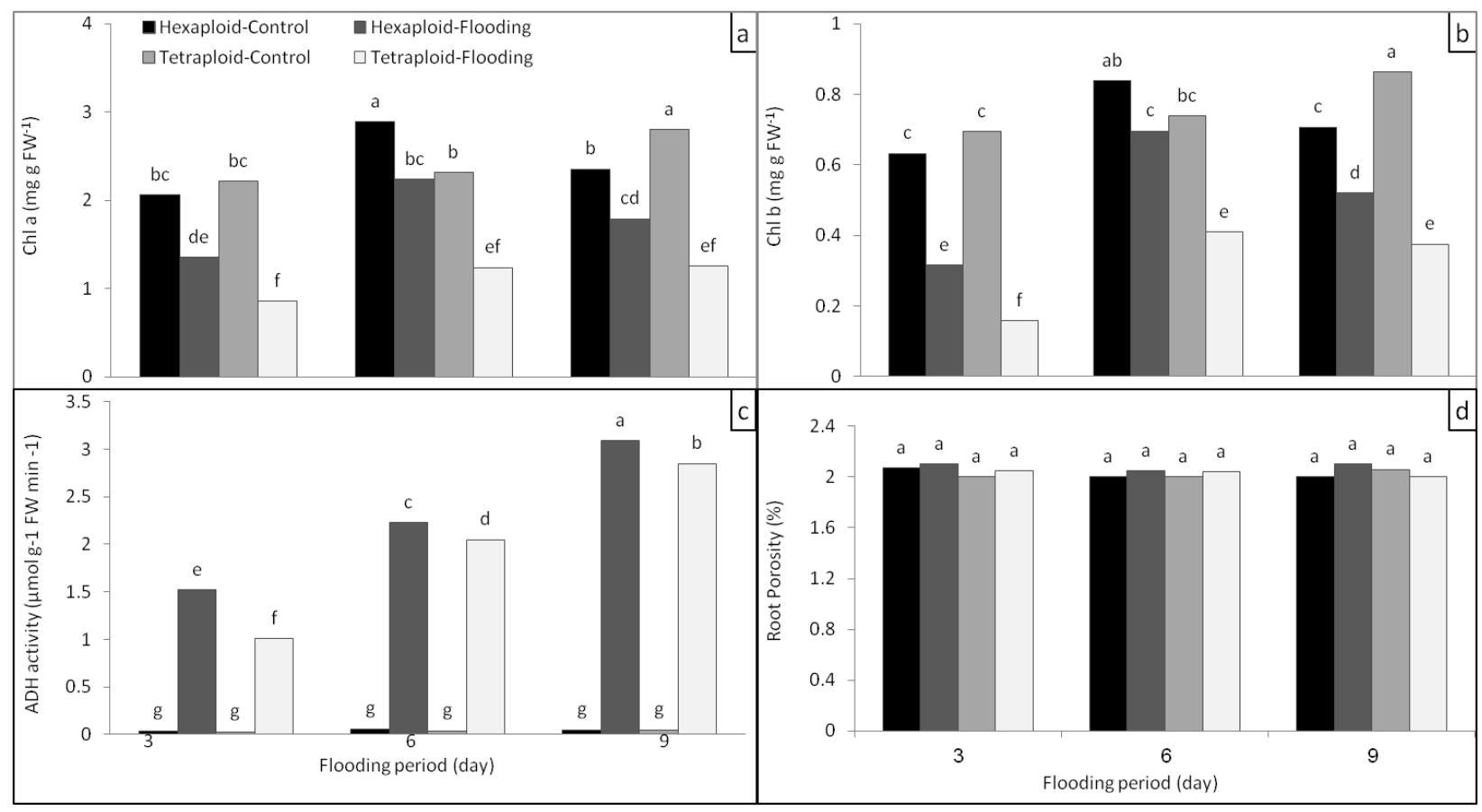

Figure 2: Changes in chlorophyll a (a) and chlorophyll b (b) content, ADH activity of root (c), and root porosity (d) of the seedlings of tetraploid and hexaploid wheat under flooding stress. Different letters indicate significant differences $(\mathrm{P}<0.05)$.

\subsection{Proline and protein content of shoot}

Flooding stress did not significantly affect shoot protein content of tetra- and hexaploid (Figure 3a). In contrast to hexaploid that proline content of shoot did not show any significant change compared to control, in tetraploid wheat it was significantly increased under all periods of flooding (Figure 3b). Shoot of tetraploid seedlings grown under 9 days flooding had the highest amount of proline relative to other treatments so that it showed a 42 percent increase relative to its control.

\subsection{Soluble sugars content}

The soluble sugar concentration in shoots of both tetraploid and hexaploid wheat was significantly decreased compared to control during all flooding treatments, except for that of hexaploid wheat under 9 days flooding. Under 3 days flooding, the concentration of soluble sugars in roots of both species was increased that was significant in case of hexaploid. Soluble sugar content in root of tetra- and hexaploid was not significantly changed under 6 and 9 days flooding, except that it was decreased in tetraploid under 6 day flooding (Figure $3 \mathrm{c} \& \mathrm{~d}$ ). 


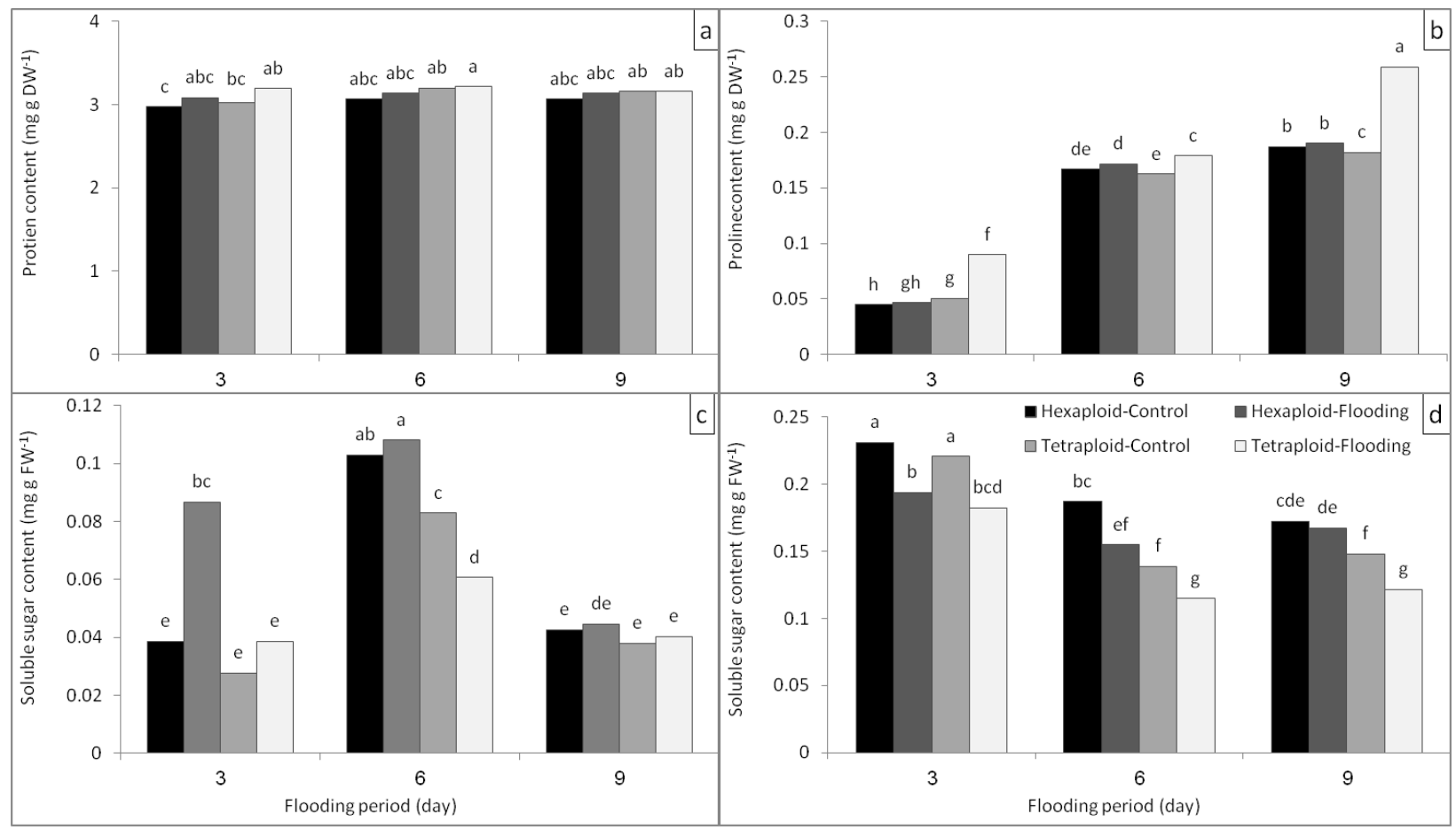

Figure 3: Changes in protein (a) and proline (b) content of shoot, and soluble sugar content of root (c) and shoots (d) of the seedlings of tetraploid and hexaploid wheat. Different letters indicate significant differences $(\mathrm{P}<0.05)$

\section{DISCUSSION}

Changes in the growth under flooding condition were reported in many plants such as pea, maize, and winter wheat (Przywara and Stepniewski, 2000; Lizaso et al., 2001; Huang et al., 1994). Under flooding condition, aerobic respiration and cellular ATP production can be reduced resulting in lack of energy to support physiological processes led to the reduced growth and crop yield (Fukao and Bailey, 2004; Taiz and Zeiger, 2010). It was reported that some plants such as wheat failed to absorb nutrient elements by roots and transport them to the shoot, resulting in mineral deficiencies that can subsequently led to the disrupting plant growth and development (Taiz and Zeiger, 2010).

Under flooding condition, net photosynthesis may also be suppressed by several mechanisms such as decrease in chlorophyll content that was observed in present study, resulted in a decrease in growth and development. In a study, barley plants exposed to the flooding for 3 days showed a remarkable decrease in photosynthesis and dry matter accumulation (Yordanova and Popova, 2001). Flooding can generally accelerate leaf senescence due to the chlorophyll degradation by a peroxidase-mediated mechanism (Hurng and Kao, 1994).

Under moderate flooding conditions, the concentration of soluble sugars in roots of hexaploid wheat was increased. This may be one of the mechanisms related to its relatively greater waterlogging-tolerance than tetraploid one. A genotype with a sufficient root sugar levels has a better chance of survival under anaerobic condition (Sairam et al., 2008). Under anaerobic condition, maintaining an adequate concentration of fermentable sugars in roots can help plants for longterm survival. In water-saturated soils, plants capable of converting the residual starch to fermentable carbohydrates are generally more tolerant to flooding stress (Guglielminetti et al., 2001; Ismail et al., 2009). However, the reduction of soluble sugars in shoot sugar content of both wheat species could be related to the decline in photosynthesis under flooding condition. Decline in photosynthesis under anaerobic condition has been observed in other cultivars of wheat (Huang et al., 1994).

Developing aerenchyma, a tissue having gas-filled spaces, in roots of wetland plants can help them to tolerate anaerobic condition. However, aerenchyma can be developed in the stem base and newly developing roots (Taiz and Zeiger, 2010). Nevertheless, in present study the root porosity of any species of wheat was not affected by flooding. This may be indicate that formation of aerenchyma is not a tolerating mechanism under flooding or may be due to this fact that present study were conducted in the seedling stage so that plants 
did not have sufficient time to develop aerenchyma. Verifying later speculation, in a study on two wheat genotypes, root porosity was increased after treating plants under flooding for 21 days (Huang and Johnson, 1995). Flooding-tolerant species such as Rumex sp. tend to develop root porosity (Laan et al., 1989). Flooding tolerant species of clover such as Trifolium fragiferum L. have more root porosity than sensitive ones such as T. glomeratum L. (Gibberd et al., 1999).

Shoot proline content of tetraploid wheat was significantly increased under flooding stress. Proline is one of the compatible solutes that its synthesis increased under different stresses. This amino acid has a high degree of solubility (Buchanan et al., 2000). Besides having a role in osmotic adjustment, proline can act as a protective factor against stress by directly or indirectly interaction with macromolecules and maintaining their natural shape and structure under stress condition. Compared to other osmoprotective solutes, proline is more efficient under stress condition. Proline also has an indirect role against stress due to its antioxidative function (Aubert et al., 2004). Proline act as an antioxidant factor via suppressing the hydroxyl radicals and some of compounds produced under stress condition that disturb electron transfer in chloroplast and mitochondria (Sousa and Sodek, 2002).

Increase in $\mathrm{ADH}$ activity under anaerobic condition was reported to be due to an early increase in the lactate concentration as a signal in the early stage of flooding condition. This interaction between lactic and ethanolic fermentation can lead to the cytoplasmic pH (Roberts et al., 1984). Consistent with this, accumulation of ethanol was reported in the endosperm of castor bean under anaerobic condition (Donaldson et al., 1985). Induction of ADH activity in roots of barely under hypoxia (Good and Crosby, 1989) and in that of soybean under anoxia (Neuman and Van Toai, 1991) has been reported.

Different responses of wheat species with different ploidy levels to environmental stresses have been reported by many researchers. It was known that, hexaploid $T$. aestivum has better tolerance to different environmental stresses such as salt, low $\mathrm{pH}$, and aluminum toxicity, and also better resistance to several pests and diseases, compared to tetraploid wheat. This is because of the fact that in the new allopolyploid species different genomes with potential of adaption to different environments are converged, leads to the potential of new emerged cultivars for tolerating a wide range of environmental conditions (Dubcovsky and Jan Dvorak, 2007). Li et al. (2017) have investigated photosynthetic response of tetraploid and hexaploid wheat to water stress and concluded that the effects of water stress on the photosynthetic performance were species dependent. Their results showed the improved performance of tetraploid wheat ears under water stress, attributed by researchers to its more efficient water utilization. Consistent with our study, in another work on different responses of hexaploid and tetraploid wheat to drought stress it was showed that under drought stress, proline accumulation in hexaploid wheat was more than that of tetraploid one (Chandrasekar et al., 2000).

\section{CONCLUSIONS}

In summary, flooding stress induced some adaptive responses in physiological levels such as increase in proline content, soluble sugar, and ADH activity of the investigated wheat species in which some responses were different. In tetrapoid wheat, an increase in proline content seemed to be one of the mechanisms for tolerating flooding stress. In hexaploid wheat, the increase in soluble sugar was a defense mechanism for better tolerance to moderate flooding stress.

\section{ACKNOWLEDGMENTS}

The authors wish sincere thanks to Alireza Hemmat and

Saber Arabi for managing the phytotronic chambers.

\section{REFERENCES}

Aggarwal, P. K., Kalra, N., Chander, S., Pathak, H. A. (2006). Dynamic simulation model for the assessment of crop yields, losses due to pests, and environmental impact of agroecosystems in tropical environments. I. Model description. Agricultural Systems, 89, 1-25. doi:10.1016/j.agsy.2005.08.001
Ashraf, M. A. (2012). Waterlogging stress in plants.: A review. African Journal of Agricultural Research, 7(13), 1976-1981.

Aubert, S., Hennion, F., Bouchereau, A., Gout, E., Bligny, R., Dome, A. J. (2004). Subcellular 
compartmentation of proline in the leaves of the subantarctic kerguelen cabbage Pringlea antiscorbiotica R.Br. invivo $\mathrm{C}^{13}$ - NMR study. Plant, Cell \& Environment, 22, 255-259. doi:10.1046/j.1365-3040.1999.00421.x

Bacanamwo, M., Purcell L. C. (1999). Soybean root morphological and anatomical traits associated with acclimation to flooding. Crop Science, 39, 143-149. doi:10.2135/cropsci1999.0011183X003900010023 $\mathrm{x}$

Bates, L., Waldren R. P., Teatre, J. D. (1973). Rapid determination of free proline for water stress studies. Plant and Soil, 39, 205-207. doi:10.1007/BF00018060

Bouny, J.M., and Saglio, P. H. (1996). Glycolytic flux and hexokinase activities in anoxic maize root tips acclimated by hypoxic pretreatment. Plant Physiology, 111, 187-194. doi:10.1104/pp.111.1.187

Buchanan, B.B., Gruissem, W., Jones, R.L. (2000). Biochemistry and molecular biology of plants. United Kingdom, Wiley-Blackwell, Lincoln.

Chandrasekar, V., Sairam, R. K., Srivastava, G. C. (2000). Physiological and biochemical responses of hexaploid and tetraploid wheat to drought stress. Journal of Agronomy and Crop Science, 185, 219227. doi:10.1046/j.1439-037x.2000.00430.x

Davies, M. S., Hillman, C. (1988). Effects of soil flooding on growth and grain yield of populations of tetraploid and hexaploid species of wheat. Annals of Botany, 62, 597-604. doi:10.1093/oxfordjournals.aob.a087699

Donaldson, R. P., Soochan P., Zaras, A. (1985). Anaerobic stress in germinating castor bean, ethanol metabolisem, and effects on subcellular organelles. Plant Physiology, 77, 978-983. doi:10.1104/pp.77.4.978

Drew, M. C. (1997). Oxygen deficiency and root metabolism: injury and acclimation under hypoxia and anoxia. Annual Review of Plant Physiology and Plant Molecular Biology, 48, 223-250. doi:10.1146/annurev.arplant.48.1.223

Dubcovsky, J., Dvorak, J. (2007). Genome plasticity a key factor in the success of polyploid wheat under domestication. Science, 316 (5833), 1862-1866. doi:10.1126/science.1143986

Fausey, N. R., Van T. T., McDonald, M. B. (1985). Response of ten corn cultivars to flooding. Transactions of the ASAE, 28, 1794-7. doi:10.13031/2013.32520

Fukao, T., Bailey-Serres, J. (2004). Plant responses to anoxia-is survival a balancing act? Trends in
Plant Science, $\quad 9, \quad 449-456$.

doi:10.1016/j.tplants.2004.07.005

Gibberd, M. R., Colmer, T. D., Cocks P. S. (1999). Root porosity and oxygen movement in waterloggingtolerant Trifolium tomentosum and intolerant Trifolium glomeratum. Plant, Cell \& Environment, 22, 1161-1168. doi:10.1046/j.13653040.1999.00472.x

Guglielminetti, L., Busilacchi, H. A., Rata, P., Alpi, A. (2001). Carbohydrate-ethanol transition in cereal grains under anoxia. New Phytologist, 151, 607612. doi:10.1046/j.0028-646x.2001.00218.x

Hoffman, N.E., Bent, A.F., Hanson, A.D. (1986). Induction of lactate dehydrogenase isozymes by oxygen deficit in barley root tissue. Plant physiology, 82, 658-663. doi:10.1104/pp.82.3.658

Hsu, F. H., Lin, J. B., Chang, S. R. (2000). Effects of waterlogging on seed germination, electric conductivity of seed leakage and development of hypocotyls and radical in sudan grass. Botanical Bulletin of Academia Sinica, 41, 267-273.

Huang, B., Johnson, J. W., Nesmith, S., Bridges, D. C. (1994). Growth, physiological, and anatomical responses of two wheat genotypes to waterlogging and nutrient supply. Journal of Experimental Botany, 45, 193-202. doi:10.1093/jxb/45.2.193

Huang, B., Johnson, J.W. (1995). Root respiration and carbohydrate status of two wheat genotypes in response to hypoxia. Annals of Botany, 75, 427432. doi:10.1006/anbo.1995.1041

Hurng, WP, Kao, C. H. (1994). Effect of flooding on the activities of some enzymes of activated oxygen metabolism, the levels of antioxidants, and lipid peroxidation in senescing tobacco leaves. Plant Growth Regulation, 14, 37-44. doi:10.1007/BF00024139

Ismail, A. M., Ella, E. S., Vergara, G. V., and Mackill, D. J. (2009). Mechanisms associated with tolerance for flooding during germination and early seedling growth in rice (Oryza sativa L.). Annals of Botany, 103, 197-209. doi:10.1093/aob/men211

Jackson, M. B. (2002). Long-distance signaling from roots to shoots assessed: the flooding story. Journal of Experimental Botany, 53, 175-181. doi:10.1093/jexbot/53.367.175

Jamei, R., Heidari, R., Khara. J., Zare, S. (2008). The interaction effects of flooding and kinetin on growth criteria, chlorophyll content, and 5aminolevulinic acid dehydratase activity in corn seedlings. Turkish Journal of Biology, 32, 53-257.

Jensen, C. R., Luxmoore, R. J., Van, G. S. D, Stolzy, L. H. (1969). Root air space measurements by a

Acta agriculturae Slovenica, 111 - 2, september 2018 
pycnometer method. Agronomy Journal, 61, 474475.

doi:10.2134/agronj1969.00021962006100030045x

Kozlowski, T. T. (1997). Response of woody plants to flooding and salinity. Tree Physiology, 1, 1-29. doi:10.1093/treephys/17.7.490

Laan, P., Berrevoets, M. J., Lythe, S., Armstrong, W., Blom, C. W. P. M. (1989). Root morphology and aerenchyma formation as indicators of the floodtolerance of Rumex species. Journal of Ecology, 77, 693-703. doi:10.2307/2260979

Li., Y. P., Li, Y. Y., Li, D. Y., Wang, S. W., Zhang, S. Q. (2017). Photosynthetic response of tetraploid and hexaploid wheat to water stress. Photosynthetica. DOI: 10.1007/s11099-016-0659y. doi:10.1007/s11099-016-0659-y

Liao, C. T., Lin, C. H. (2001). Physiological adaptation of crop plants to flooding stress. Proceedings of the National Science Council, Republic of China. Part $B, 25,148-157$.

Lichtenthaler, H. K., Wellbum, A. R. (1983). Determination of total carotenoids and chlorophylls $\mathrm{a}$ and $\mathrm{b}$ of leaf extracts in different solvents. Biochemical Society Transactions, 11, 591-592. doi:10.1042/bst0110591

Lizaso, J. I., Melendez, L. M., Ramirez, R. (2001). Early flooding of two cultivars of tropical maize. I. Shoot and root growth. Journal of Plant Nutrition, 24, 979-995. doi:10.1081/PLN-100103798

Lowery, O. H., Rosebrough, N. J., Farr, A. L., Randal, R. J. (1951). Protien measurement with the folin phenol regent. The Journal of Biological Chemistry, 163, 265-275.

Mousavi Kouhi, S. M., Lahouti, M., Ganjeali, A. Entezari, M. H. (2014). Comparative phytotoxicity of $\mathrm{ZnO}$ nanoparticles, $\mathrm{ZnO}$ microparticles, and $\mathrm{Zn}^{2+}$ on rapeseed (Brassica napus L.): investigating a wide range of concentrations. Toxicological \& Environmental Chemistry, 96 (6), 861-868. doi:10.1080/02772248.2014.994517

Neuman, K. D., Van Toai, T. T. (1991). Developmental regulation and organ specific expression of soybean alcohol dehydrogenase. Crop Science, 31, 1253-
1257.

doi:10.2135/cropsci1991.0011183X003100050034 $\mathrm{X}$

Przywara, G., Stepniewski, W. (2000). Influence of flooding and different temperatures of the soil on gas-filled porosity of pea, maize and winter wheat roots. International Agrophysics, 14, 401-410.

Roberts, J. K. M., Callis, J., Jardetzky, O., Walbot, V., Feeling, M. (1984). Cytoplasmic acidisis as a determinant of flooding intolerant in plants. Proceedings of the National Academy of Sciences, 81, 6029-6033. doi:10.1073/pnas.81.19.6029

Sairam, R. K, Kumutha, D., Ezhilmathi, K., Deshmukh, P. S., Srivastava, G. C. (2008). Physiology and biochemistry of waterlogging tolerance in plants. Biologia Plantarum, 52, 401-412. doi:10.1007/s10535-008-0084-6

Sousa, C. A. F., Sodek, L. (2002). The metabolic response of plants to oxygen deficiency. Brazilian Journal of Plant Physiology, 14 (2), 83-94. doi:10.1590/S1677-04202002000200002

Taiz, L., Zeiger, E. (2010). Plant physiology. Fifth edition. Sunderland, Sinauer.

Vantoai, T., Fausey, N., McDonald, M. (1988). Oxygen requirements for germination and growth of floodsusceptible and flood-tolerant corn line. Crop Science, 28, 79-83. doi:10.2135/cropsci1988.0011183X002800010019 $\mathrm{x}$

Vartapetian, B. B., Jackson, M. B. (1997). Plant adaptations to anaerobic stress. Annals of Botany, 79, 3-20. doi:10.1093/oxfordjournals.aob.a010303

Yordanova, R., Popova, L. 2001. Photosynthetic response of barley plants to soil flooding. Photosynthetica, 39, 515-520. doi:10.1023/A:1015643710177

Yang, C., Zhao, L., Zhang, H., Yang, Z., Wang, H., Wen, S., Zhang, C., Rustgi, S., Wettstein, D. V., Liu, B. (2014). Evolution of physiological responses to salt stress in hexaploid wheat. PNAS, $111 \quad$ (32), 11882-11887 doi:10.1073/pnas.1412839111. 